\title{
Carburization Degree of Iron Nugget Produced by Rapid Heating of Powdery Iron, Iron Oxide in Slag and Carbon Mixture
}

\author{
Ko-ichiro OHNO, ${ }^{1)}$ Takahiro MIKI, ${ }^{2)}$ Yasushi SASAKI ${ }^{3)}$ and Mitsutaka HINO ${ }^{2)}$ \\ 1) Formerly Graduate Student, Tohoku University. Now at Department of Material Science and Engineering, Kyushu \\ University, Motooka 744, Nishi-ku, Fukuoka 819-0395 Japan. $\quad$ 2) Graduate School of Engineering, Tohoku University, 6-6- \\ 02 Aoba-yama, Aoba-ku, Sendai 980-8579 Japan. $\quad 3$ 3) Formerly Graduate School of Engineering, Tohoku University. Now \\ at Graduate Institute of Ferrous Technology, POSTECH, San 31 Hyoja-Dong, Nam-Gu, Pohang, Gyeongbuk $790-784$ Korea.
}

(Received on May 15, 2008; accepted on July 14, 2008)

\begin{abstract}
Iron nugget making process by rapid heating reduction of powdery iron ore and pulverized coal mixture is regarded as one of the novel iron-making processes. Iron carburization during smelting reduction is especially important reaction step from the viewpoint of saving energy in this process. If the rate and efficiency of carburization reaction are increased, energy consumption of the process will be reduced to large extent. The purpose of this study is to clarify the carburization degree of iron nugget during smelting reduction of the mixture.

The sample was prepared from graphite, electrolytic iron powder and synthetic slag containing iron oxide to simulate iron carburization phenomena during smelting reduction of the mixture in the present work. The sample was quenched immediately after the mixture changed into nugget shape in a rapid heating process. Laser microscope combined with infrared image furnace was used for sample heating and observation of carburization phenomena, and carbon content in the nugget was chemically analyzed after quenching.

From above-mentioned investigations, it was revealed that the occurrence of carburization during smelting reduction in the sample mixture is advantageous to obtain higher carbon contain iron nugget.
\end{abstract}

KEY WORDS: novel iron making process; iron carburization; smelting reduction; confocal laser microscope combined with infrared image furnace.

\section{Introduction}

Iron nugget making process by rapid heating reduction of powdery iron ore and pulverized coal mixture draws our attention as one of the novel iron-making process. ${ }^{1-3)}$ The process completes quickly within $15 \mathrm{~min}$ the following reactions of iron ore reduction, smelting reduction, iron carburization and slag separation. This process has a great advantage in energy saving compared with the conventional ironmaking process, because the conventional one requires about $6-8 \mathrm{~h}$ for pig iron production. Therefore, iron carburization step is especially important in all steps of the present ironmaking process, because the melting temperature of reduced iron is controlled by carbon content.

It is generally considered that reduced iron is carburized by direct contact of residual carbon and carbonaceous gas formed during rapid heating process. Murakami and Nagata $^{4)}$ has researched the mechanism of iron carburization. However, they have not considered the effect of iron oxide in molten slag formation on the carburization degree. There are a lot of possibilities for iron carburization during smelting reduction process, as shown in Fig. 1. Nagasaka and Ban-ya, ${ }^{5)}$ and Tsukihashi et al. ${ }^{6}$ have studied the smelting reduction rate, but they have not discussed the relation between degrees of smelting reduction and iron carburization.
In our previous works, ${ }^{7,8)}$ the mechanism of iron carburization during smelting reduction has gradually made clear.

The purpose of this study is to clarify the factors of carburization degree of iron nugget during smelting reduction of powdery iron ore and pulverized coal mixture.

\section{Experiment}

The phenomena in the rapid heating process of the mix-

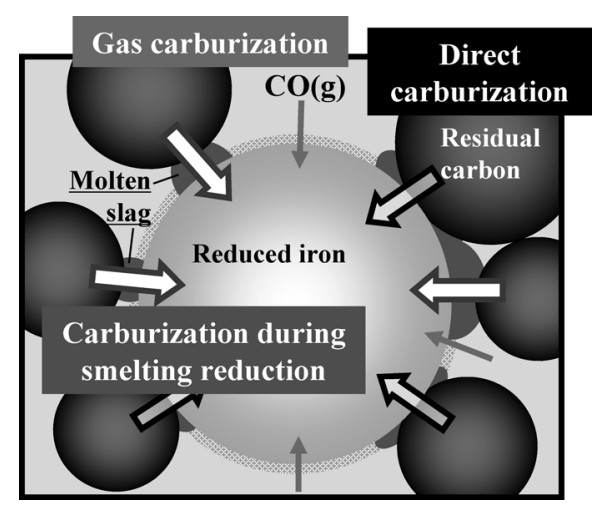

Fig. 1. Illustration of carburization phenomena in the powdery iron ore and pulverized coal mixture during rapid heating. 


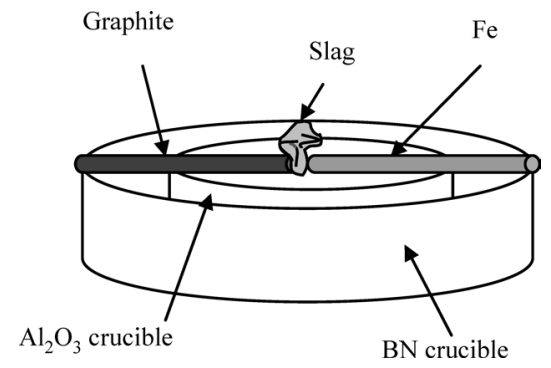

Fig. 2. Schematic sketch of sample set up for Micro-experiment. ${ }^{7,8)}$

ture would be complex due to the presence of reduced iron, formed slag and residual carbon phases. In the present work, reproduction of the reactions between carbon, slag and iron was made at the ironmaking temperature. A confocal laser-scanning microscope combined with an infrared image-heating furnace, ${ }^{9)}$ which enabled us to make microscopic "in-situ" observation at high temperature, was used in the present work.

\subsection{Samples}

Two kinds of experiments were carried out in this work to make the phenomena clear. First experiment was microscopic "in-situ" observation in micro model reproducing the inside situation of the mixture (hereinafter "Micro-experiment") during heating experiment. The same technique and assembly as our previous works ${ }^{7,8)}$ was utilized for Micro-experiment as shown in Fig. 2.

The mixture sample was heated in another experiment, which simulated the reaction among the carbonaceous material, the molten slag and the completely reduced iron ore (hereinafter "Macro-experiment"). Graphite, synthesized slag and electrolytic iron powder were used as fixed carbon included in coal, coal ash and gangue, and reduced iron in the heating process, respectively. The mixing ratios of these powders were decided on the basis of following ideas; $10 \mathrm{wt} \%$ of $\mathrm{Fe}$ in the mixture is replaced by un-reduced iron oxide as $\mathrm{Fe}_{t} \mathrm{O}$ in slag. The $\mathrm{Fe}_{t} \mathrm{O}$ concentration in the slag is fixed at $60 \mathrm{wt} \%$. Carbon is added to the mixture for two roles. One role is for complete reduction of $\mathrm{Fe}_{t} \mathrm{O}$ in the slag. Another is for carburization of total $\mathrm{Fe}$ which consists of reduced iron form $\mathrm{Fe}_{t} \mathrm{O}$ in slag and pre-added Fe. They were well-mixed each other as shown in Table 1 and the powder was pressed into tablet shape using dies of $5 \mathrm{~mm}$ diameter.

The sample was put into a BN crucible and covered with another BN crucible with an observation hole as shown in Fig. 3. A tablet sample that contained only iron and graphite powder was also prepared for the comparison.

The synthetic slag was prepared by melting the reagent grade oxide mixtures. At first, two kinds of master slag were prepared as shown in Fig. 4. ${ }^{10)}$ 20, 30, 40 and 60 mass $\% \mathrm{Fe}_{t} \mathrm{O}$ containing slags were prepared by adding $\mathrm{Fe}_{t} \mathrm{O}$ to the master slag. Each slag was melted and quenched in an $\mathrm{Al}_{2} \mathrm{O}_{3}$ crucible using the infrared imageheating furnace.

\subsection{Experimental Procedures}

In the Micro-experiment, a sample was set in the sample chamber of the infrared image-heating furnace and then heated up to $1673 \mathrm{~K}$ at the heating rate of $3.33 \mathrm{~K} / \mathrm{s}(200$
Table 1. Material mixing ratio in slag containing experimental tablets (weight ratio).

(a) Final carbon content in iron nugget to be produced : $3 \mathrm{wt} \%$

\begin{tabular}{|c|c|c|c|}
\hline \multirow{2}{*}{$\begin{array}{c}\text { Electrolytic } \\
\text { iron powder }\end{array}$} & $\begin{array}{c}\text { 60wt\% FeO } \\
\text { containing synthetic } \\
\text { slag }\end{array}$ & \multicolumn{2}{|c|}{ Graphite powder } \\
\hline \multirow{3}{*}{87.30} & 20.80 & \multicolumn{2}{|c|}{5.08} \\
\cline { 2 - 4 } & (Fe content) & (for Fe, $\mathrm{O}$ Reduction) & (for Fe Carburization) \\
\cline { 2 - 4 } & 9.70 & 2.08 & 3.00 \\
\hline
\end{tabular}

(b) Final carbon content in iron nugget to be produced : $4 \mathrm{wt} \%$

\begin{tabular}{|c|c|c|c|}
\hline \multirow{2}{*}{$\begin{array}{c}\text { Electrolytic } \\
\text { iron powder }\end{array}$} & $\begin{array}{c}\text { 60wt\% FeO } \\
\text { containing synthetic } \\
\text { slag }\end{array}$ & \multicolumn{2}{|c|}{ Graphite powder } \\
\hline \multirow{3}{*}{86.40} & 20.58 & \multicolumn{2}{|c|}{6.06} \\
\cline { 2 - 4 } & (Fe content) & (for $\mathrm{Fe}_{t} \mathrm{O}$ Reduction) & (for Fe Carburization) \\
\cline { 2 - 4 } & 9.60 & 2.06 & 4.00 \\
\hline
\end{tabular}

(c) Final carbon content in iron nugget to be produced : $5 \mathrm{wt} \%$

\begin{tabular}{|c|c|c|c|}
\hline \multirow{2}{*}{$\begin{array}{c}\text { Electrolytic } \\
\text { iron powder }\end{array}$} & $\begin{array}{c}\text { 60wt\% FeO } \\
\text { containing synthetic } \\
\text { slag }\end{array}$ & \multicolumn{2}{|c|}{ Graphite powder } \\
\hline \multirow{3}{*}{85.50} & 20.37 & \multicolumn{2}{|c|}{7.04} \\
\cline { 2 - 4 } & (Fe content) & (for $\mathrm{Fe}_{t} \mathrm{O}$ Reduction) & (for Fe Carburization) \\
\cline { 2 - 4 } & 9.50 & 2.04 & 5.00 \\
\hline
\end{tabular}
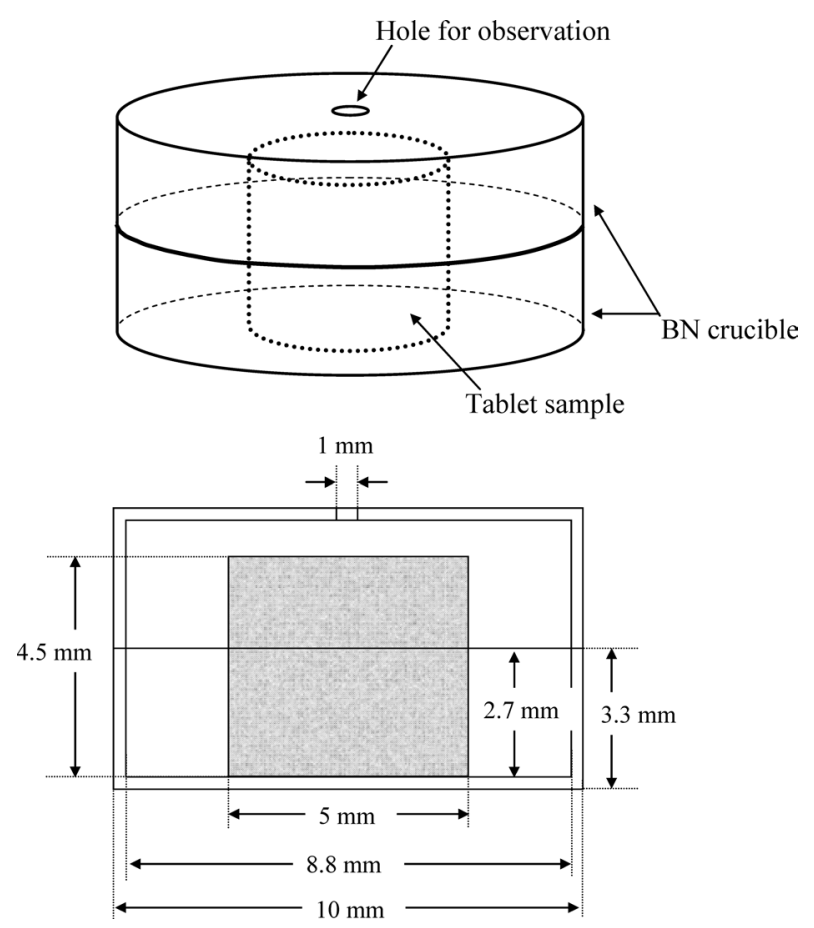

Fig. 3. Schematic sketch of sample set up for Macro-experiment.

$\mathrm{K} / \mathrm{min}$ ) in an argon atmosphere. After the temperature reached at $1673 \mathrm{~K}$, the sample was kept during confirmable period of reduction reaction at this temperature and then quenched by turning the power of the furnace off.

In the Macro-experiment, a sample was also set in the sample chamber and then heated up to $1273 \mathrm{~K}$ rapidly at the heating rate of $16.6 \mathrm{~K} / \mathrm{s}(1000 \mathrm{~K} / \mathrm{min})$ for prevention of $\mathrm{Fe}_{t} \mathrm{O}$ reduction in slag under an argon atmosphere. Then, the sample was continuously heated at $3.33 \mathrm{~K} / \mathrm{s}(200 \mathrm{~K} / \mathrm{min})$ until the sample melted down in an argon atmosphere and quenched immediately after melting down.

Phenomena during heating process in both experiments 


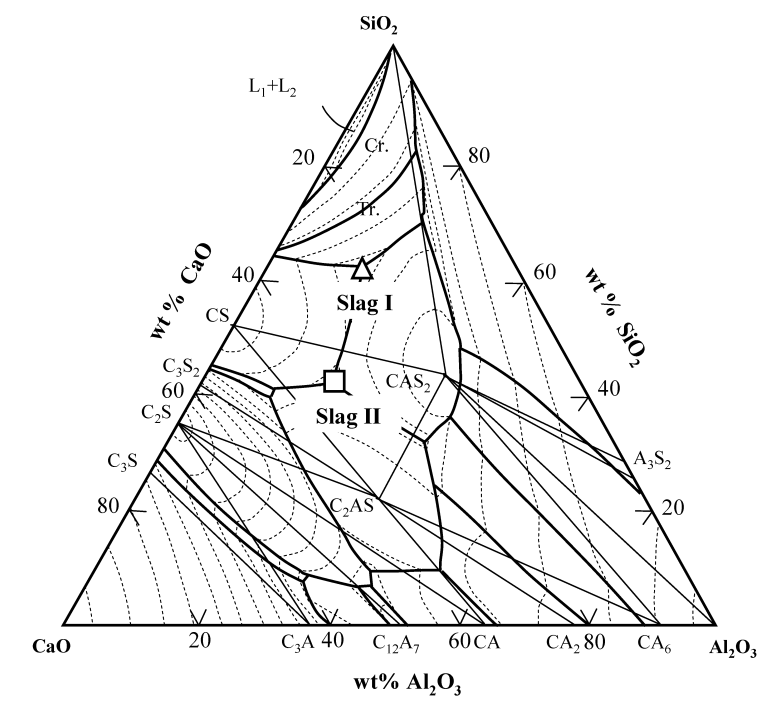

\begin{tabular}{|l|c|c|c|c|c|}
\hline & \multicolumn{3}{|c|}{ Slag Composition (wt $\%)$} & (mass ratio) & \multirow{2}{*}{$\begin{array}{c}\text { Melting } \\
\text { point }(\mathrm{K})\end{array}$} \\
\cline { 2 - 5 } & $\mathrm{CaO}$ & $\mathrm{Al}_{2} \mathrm{O}_{3}$ & $\mathrm{SiO}_{2}$ & $\mathrm{CaO} / \mathrm{SiO}_{2}$ & \\
\hline$\triangle$ Slag I & 23.37 & 14.69 & 61.94 & 0.38 & 1443 \\
\hline$\square$ Slag II & 38.23 & 20.06 & 41.71 & 0.92 & 1538 \\
\hline
\end{tabular}

Fig. 4. Experimental slag composition for "in-situ" observation. $^{11)}$

were observed on CRT monitor of the laser microscope and were recorded by VTR equipment.

After quenching sample in the Macro-experiment, carbon concentration of the obtained iron nugget in the tablet sample was determined by infrared adsorption technique. $\mathrm{Fe}_{t} \mathrm{O}$ concentration in formed slag after heating experiment was also determined by EDS (energy-dispersive X-ray analysis).

\section{Result and Discussion}

\section{1. "In-situ" Observation of Smelting Reduction}

In Micro-experiment, the result of "in-situ" observation was trucked in terms of $\mathrm{CO}$ gas formation during smelting reduction as shown in Fig. 5.

The relation between slag melting temperature and starting temperature of $\mathrm{CO}$ gas formation is shown in Figs. 6 and 7, when slag I and slag II were used, respectively. It makes clear from these results that slag I needs some temperature rise for $\mathrm{CO}$ gas formation after slag melts down. However, slag II does not need any temperature rise after slag melts down. In other words, CO gas was immediately formed at slag melting temperature. Figure 8 shows the period of smelting reduction time, which is defined as the continuous observation period of $\mathrm{CO}$ gas formation. The smelting reduction period on the condition using the slag II was shorter than that using slag I.

It can be said from these results of smelting reduction "in-situ" observation that slag II has an advantage for effective smelting reduction.

Generally, the rate of smelting reduction with solid carbon, $r$, can be defined by following equation.

$$
r=-\left(d W_{\mathrm{O}} / d t\right) / A \quad\left[\mathrm{~kg} \text {-oxygen } / \mathrm{m}^{2} \mathrm{~s}\right]
$$

Where, $W_{\mathrm{O}}$ [kg-oxygen] is the amount of removed oxygen caused by smelting reduction, $t[\mathrm{~s}]$ is reaction time, and $A$ $\left[\mathrm{m}^{2}\right]$ is interfacial area of reaction.
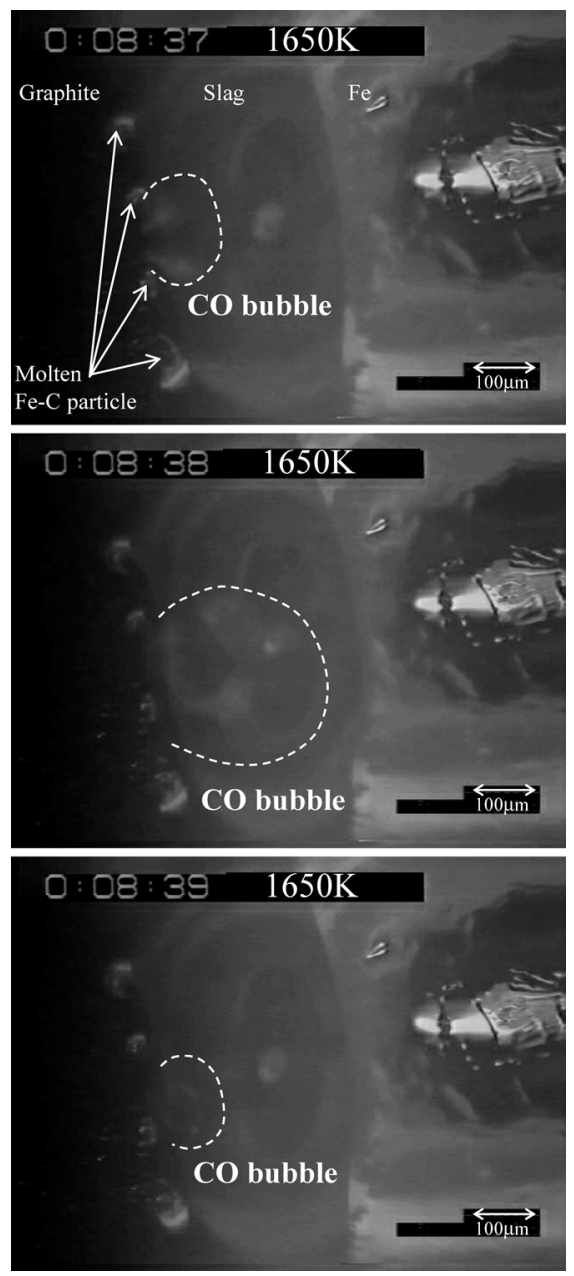

Fig. 5. Laser micrograph and schematic sketch of the sample at $1650 \mathrm{~K} .^{7,8)}$

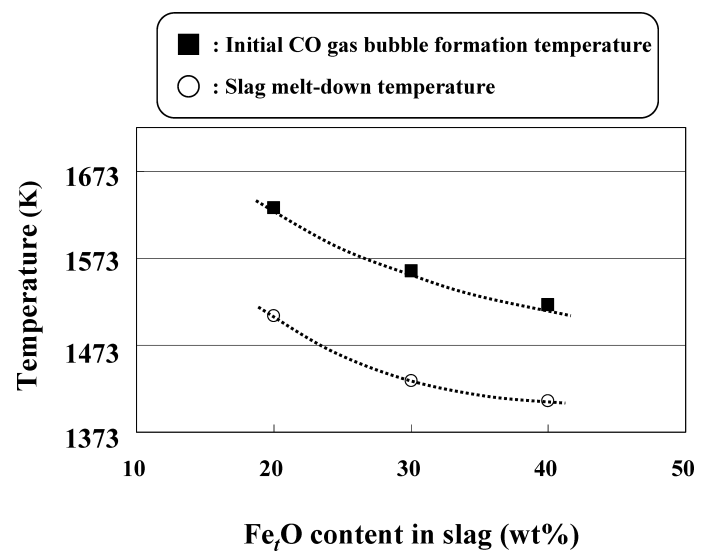

Fig. 6. Slag melt-down temperature and initial $\mathrm{CO}$ gas bubble formation temperature with $\mathrm{Fe}_{t} \mathrm{O}$ content in master slag I $(B=0.38)$.

Nagasaka and Ban-ya ${ }^{5)}$ reviewed literature values on the reaction rate of smelting reduction by solid carbon. They carried out rearrangement of these values with apparent secondary reaction rate constant as follows,

$$
r=k^{2 \text { nd }}\left(\operatorname{mass} \% \mathrm{Fe}_{t} \mathrm{O}\right)^{2} \quad\left[\mathrm{~kg} \text {-oxygen } / \mathrm{m}^{2} \mathrm{~s}\right] .
$$

The relation between apparent secondary reaction rate constant and slag composition, as basicity of $B=\mathrm{CaO}(\mathrm{wt} \%) /$ $\mathrm{SiO}_{2}(\mathrm{wt} \%)$, was shown in Fig. 9. ${ }^{5)} k^{2 \text { nd }}$ had a peak around 


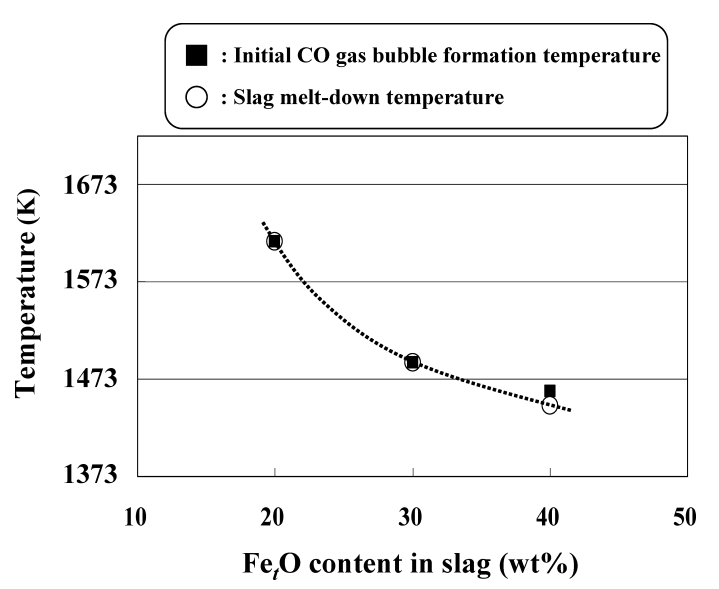

Fig. 7. Slag melt-down temperature and initial $\mathrm{CO}$ gas bubble formation temperature with $\mathrm{Fe}_{t} \mathrm{O}$ content in master slag II $(B=0.92)$.

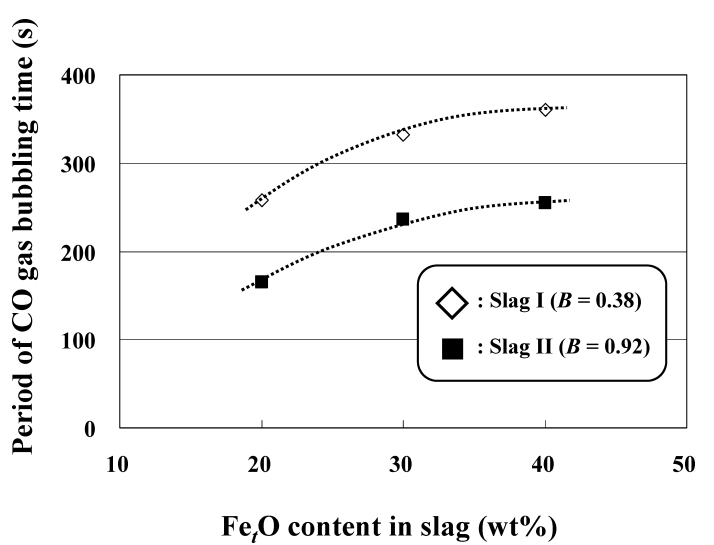

Fig. 8. Effect of master slag composition on period of $\mathrm{CO}$ gas bubbling time during heating up to $1673 \mathrm{~K}$.

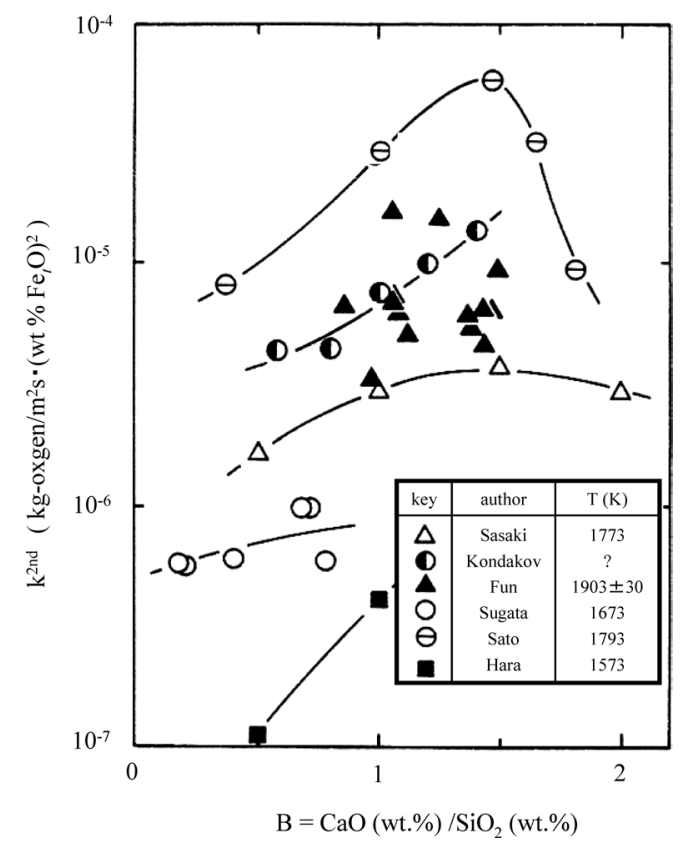

Fig. 9. Effect of basicity $\mathrm{B}$ on the apparent reduction rate of $\mathrm{Fe}_{t} \mathrm{O}$ in liquid $\mathrm{Fe}_{t} \mathrm{O}-\mathrm{CaO}-\mathrm{SiO}_{2}$ slag with solid carbon. ${ }^{5}$ )

$B=1.5$ in this figure. This trend gives us a suitable explanation for the "in-situ" observation result utilizing 2 kinds of slag in this work.

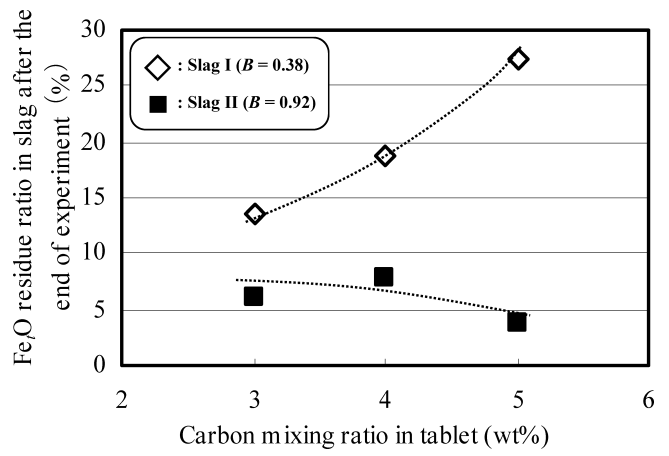

Fig. 10. $\mathrm{Fe}_{t} \mathrm{O}$ residue ratio after the end of experiment in slag I $(B=0.38)$ and slag II $(B=0.92)$.

\section{2. $\quad \mathrm{Fe}_{t} \mathrm{O}$ Residue Ratio in Slag}

In Macro-experiment, $\mathrm{Fe}_{t} \mathrm{O}$ residue ratio in slag is defined as follow equation in the present work.

$\mathrm{Fe}_{t} \mathrm{O}$ residue ratio

$$
\begin{aligned}
= & \frac{\left.\mathrm{Fe}_{t} \mathrm{O} \text { concentration in slag after the experiment ( } \mathrm{wt} \%\right)}{\mathrm{Fe}_{t} \mathrm{O} \text { concentration in slag before the experiment }(\mathrm{wt} \%)} \\
& \times 100 \quad[\%]
\end{aligned}
$$

The relation between this $\mathrm{Fe}_{t} \mathrm{O}$ residue ratio in slag after reduction and carbon mixing ratio in tablet sample is shown in Fig. 10. This result also indicates that slag II has an advantage of smelting reduction, because $\mathrm{Fe}_{t} \mathrm{O}$ residue ratio in slag II after the end of Macro-experiment was lower than that of slag I.

\subsection{Carbon Concentration of the Iron Nugget}

In Macro-experiment, the effective carbon mixing ratio $(\mathrm{wt} \%)$ is defined as following equation.

Effective carbon mixing ratio

$$
\begin{aligned}
= & \frac{\text { Carbon for carburization }(\mathrm{g})+\text { Residual carbon after reduction }(\mathrm{g})}{\text { Initial mixing electrolytic iron powder }(\mathrm{g})+\text { Formed reduced iron }(\mathrm{g})} \\
& \times 100 \quad[\mathrm{wt} \%]
\end{aligned}
$$

The effective carbon mixing ratio in the tablet is not the same value as final carbon content in iron nugget shown in Table 1.

The relation between this effective carbon mixing ratio and carbon concentration in the iron nugget is shown in Fig. 11. This result also indicates that slag II had the positive effect on carburization during smelting reduction, because the carbon concentration in iron nugget using slag II was higher than those in the other experiments by $+0.4 \mathrm{wt} \%$.

\subsection{Relation between the Carbon Concentration in the Iron Nugget and the Apparent Melt-down Temperature of the Tablet Sample}

In Macro-experiment, the apparent melt-down temperature of the tablet sample was determined as the temperature, at which the shape of tablet sample crumbled and changed to iron nugget form. The typical melt-down behavior of the tablet sample, where final carbon mixing ratio was $5 \mathrm{wt} \%$ and slag containing $\mathrm{Fe}_{t} \mathrm{O}$ was not added, is shown in Fig. 12. It could be observed generally near the 


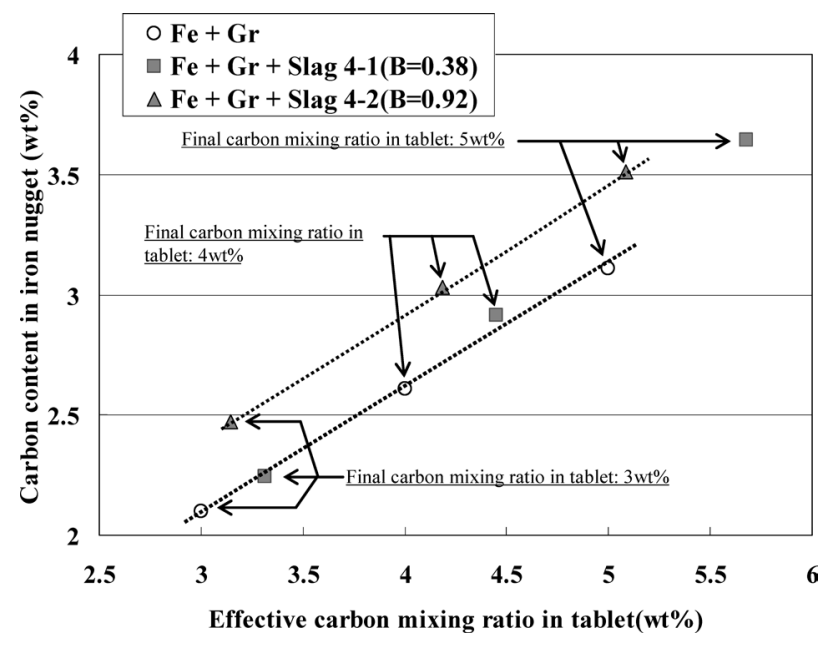

Fig. 11. Relation among effective carbon mixing ratios in tablet and on carbon contents in iron nugget.

(a)

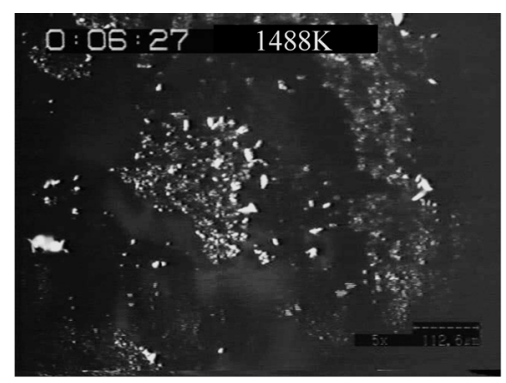

(b)
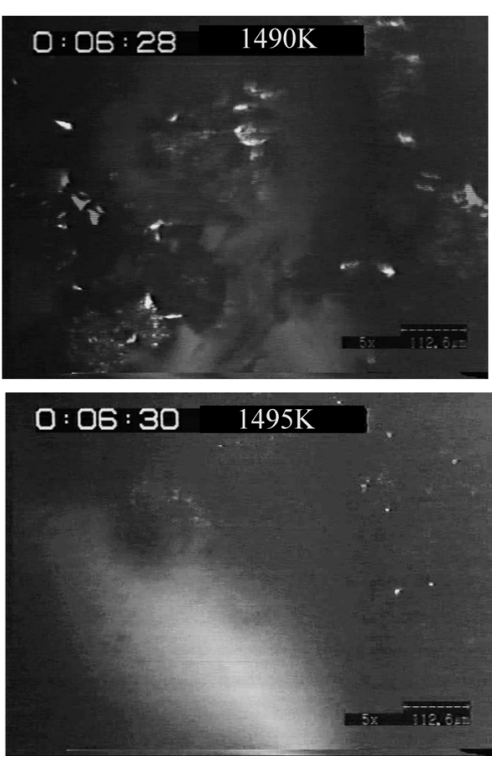

Fig. 12. Laser micrographs of tablet melt-down behavior during heating process.

eutectic temperature of $\mathrm{Fe}-\mathrm{C}$ binary alloy as shown in this figure.

Figure 13 shows the relation between the carbon concentration in the formed nugget and the apparent melt-down temperature of the tablet sample.

The results of sample, which did not include slag containing $\mathrm{Fe}_{t} \mathrm{O}$, deviated from the liquidus line ${ }^{11)}$ on the phase diagram of $\mathrm{Fe}-\mathrm{C}$ binary. This result indicated that iron powder in the tablet sample did not completely changed to liquid phase by carburization and some parts of solid iron still remained at the melt-down temperature. On the other hand, the results of samples including slag containing $\mathrm{Fe}_{t} \mathrm{O}$

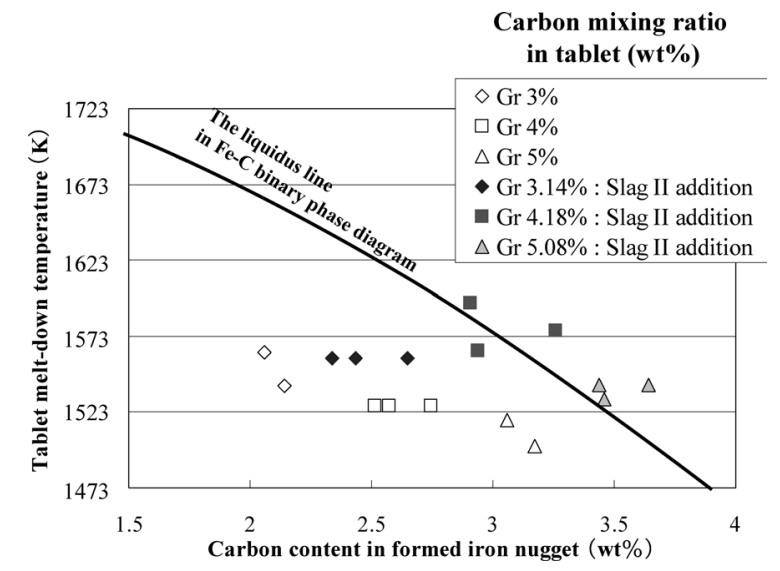

Fig. 13. Effect of $\mathrm{Fe}_{t} \mathrm{O}$ containing slag addition into tablet of iron and graphite powder mixtures on melt-down temperature of the tablet and carbon content in formed iron nugget.

were closer to the liquidus line compared with not- $\mathrm{Fe}_{t} \mathrm{O}$ including the slag. It is clear from Fig. 5 that the promotion of molten $\mathrm{Fe}-\mathrm{C}$ particle formation volume was due to smelting reduction by graphite. Therefore, the condition, where carburization during smelting reduction could occur, was advantageous to iron higher carburization of the nugget.

\section{Conclusion}

It is revealed from "in-situ" observation technique and carbon concentration analysis in the present work that the occurrence of carburization during smelting reduction in the sample mixture is advantageous to obtain higher carbon contain iron nugget. This fact indicates partial replacement of direct carburization between $\mathrm{Fe}$ and $\mathrm{C}$ by carburization during smelting reduction positively contributes to the high carbon content in iron nugget. In the mixture of powdery iron ore and pulverized coal in rapid heating process, aggressive utilization of smelting reduction will have prospects of high carbon containing iron nugget production.

\section{Acknowledgements}

The authors are grateful to Messrs. Masaki Shimamoto, now at Kobe steel, for his experimental assistance.

\section{REFERENCES}

1) T. Matsumura, Y. Takenaka, M. Shimizu, T. Negami, I. Kobayashi and A. Uragami: Tetsu-to-Hagané, 84 (1998), 405.

2) T. Matsumura, Y. Takenaka and M. Shimizu: Tetsu-to-Hagané, 85 (1999), 652.

3) Y. Sawa, T. Yamamoto, K. Takeda and H. Itaya: ISIJ Int., 41 (2001), s17.

4) T. Murakami and K. Nagata: Miner. Process. Extract. Metall. Rev., 24 (2003), 253.

5) T. Nagasaka and S. Ban-ya: Tetsu-to-Hagané, 78 (1992), 1753.

6) F. Tsukihashi, M. Amatatsu and T. Soma: Tetsu-to-Hagané, 68 (1982), 1880.

7) K. Ohno, T. Nagasaka and M. Hino: Steel Res., 74 (2003), 5.

8) K. Ohno, T. Miki and M. Hino: ISIJ Int., 44 (2004), 2033.

9) K. Tsutsumi, T. Nagasaka and M. Hino: ISIJ Int., 39 (1999), 1150.

10) Slag Atlas, 2nd ed., Verlag Stahleisen GmbH, Düsseldorf, (1995), 105.

11) ASM Handbook, Vol. 3, Alloy Phase Diagrams, ASM Int., Material Park, Ohio, (1992), 110. 